\title{
The Effect of Hallucinatory Implementation Strategies on the Patient's Ability to Control Hallucinations
}

\author{
$1^{\text {st }}$ Arifal Aris \\ Nursing Doctoral Student \\ Faculty of Nursing \\ Universitas Airlangga Surabaya \\ Surabaya \\ arifal_aris@yahoo.com \\ $4^{\text {th }}$ Siti Sholikah \\ Faculty of Health Science \\ Universitas Muhammadiyah Lamongan \\ Indonesia
}

\author{
$2^{\text {nd }} \mathrm{AH}$ Yusuf \\ Faculty of Nursing \\ Universitas Airlangga Surabaya \\ Surabaya, Indonesia \\ $5^{\text {th }}$ Abdul Rokhman \\ Faculty of Health Science \\ Universitas Muhammadiyah Lamongan \\ Indonesia
}

\author{
$3^{\text {rd }}$ Virgianti Nur Faridah \\ Faculty of Health Science \\ Universitas Muhammadiyah Lamongan \\ Indonesia
}

\begin{abstract}
Action and communication implementation strategy is a method of guidance in the implementation of actions based on the needs of patients and refers to the standard by implementing effective communication module CI Pusdiknakes training. The aims of the study was to identify the influence of the implementation strategy of hallucinations on the ability of the patient to control the hallucinations. Method. This study used Pre Experiments by using the design of One Group Pretest-Postest. The sample a lot 80 respondents are Patients who have mental disorder hallucinations. This research data is taken by using SOP. Then tabulated using Wilcoxon test with a significance level of 0.05. Results. Based on Wilcoxon test results obtained $Z=$ $5.831 b$ and $p=0,000$ where $p<0.05$. Showed that there is influence of implementation of hallucinations implementation strategy on patient ability to control hallucinations. Conclusion. Nursing always be used as activities, because little or much will Influence implementation of implementation strategy hallucinations to patient ability controlling hallucinations.
\end{abstract}

\section{Keywords-Hallucinatory, Strategies, Patient}

\section{INTRODUCTION}

Mental health is an internal part of health efforts aimed at creating a healthy mental development of optimally both intellectual and emotional. Mental health problems have a very broad scope and complex and interconnected each other. Mental health is also called as a healthy condition of emotional, psychological and social visible from satisfying interpersonal relationships, behavior and effective coping, positive self concept and emotional stability. If the individual is unable to maintain balance or maintain prosperous mental condition, then the individual will be impaired, and if it is a psychological disorder that would result to individuals having mental disorders [1].
Mental disorders is the unability to communicate or recognize the realities which raises difficulties in a person's ability to participate as appropriate in daily life. Mental disorders are divided into two major parts, that is mild mental disorder (Neurosa) and severe mental disorders (Psychosis). Psychosis there are 2 types that is organic psychosis, where abnormalities are found in the brains and functional psychosis, there are no abnormalities in the brain.

Mental disorder causes the sufferers unable to adequately assess reality, no longer able to control herself in order to prevent disturbing others or damage harm himself. Actually mental disorders is same with other physical disorders. It's just that mental disorders are more complex, ranging from mild such as anxiety, fear to the level of mental illness or a severe form known as mad [2]. Signs and symptoms of psychosis is: behavioral regression, the feelings do not appropriate, the reduced oversight of impulses, delusions and hallucinations.

According to the World Health Organization (WHO), amount of people with mental disorders in the world in 2001 was 450 millions. With reference to these data, now that number is estimated to have increased. It is estimated that of the approximately 220 million people in Indonesia, there are 50 million or 22 percent, having psychiatric disorders [3]. An increasing amount of people with mental disorders is also occur in North Sumatra, amount of patients increased by 100 percent compared with previous years. In early 2008, RSJ Sumatra receives about 50 patients in one day to be hospitalized and about 70-80 patients for outpatient care. While in 2006-2007, RSJ only receiving 25-30 patients in one day [4]. 
Patients were treated at a mental hospital in Indonesia have an average length of hospitalization days were as high as 54 days, and the longest being treated is a patient with a diagnosis of schizophrenia. Data Bogor central mental hospital in 2001, shows the average length of the hospitalization was 115 days and 42 days for patients with violent behavior [5].

In Indonesia based on Riskesdas [6] that the prevalence of severe mental disorders was 4,6 in every one mil, it means that there are four until five people from Indonesia 1000 population suffer from severe mental disorders. Figures mental disorders in Indonesia has reached $10 \%$ of the population penduduknya. According to WHO [7] if $10 \%$ of the population having mental health problems then it should be given due attention has been categorized as prone to mental health that need to be taken seriously by all parties.

In East Java, $1.4 \%$ and Surabaya totaled $0.2 \%$. While the emotional mental disorders (such as anxiety, depression, etc.) $35 \%$ and $18.8 \%$ recorded in Surabaya.

In the psychiatric hospital menur Surabaya on November 10, 2016 get 1,679 people who are having mental disorders in Menur psychiatric hospitals with impaired sensory perception (hallucinations) by $30 \%$ or 503 clients, social isolation (withdraw) by $25 \%$ or 420 client, violent behavior as much as $15 \%$ or 252 clients, impaired self concept (low self esteem) as much as $12 \%$ or 202 clients, delusions as much as $7 \%$, or 117 clients and suicide as much as $1 \%$ or 17 clients.

Based on the initial survey carried out on 12 March 2017 in get 118 people with mental disorders in the clinic Turi lamongan $50 \%$ or 59 clients with hallucinations, $30 \%$ or 35 clients withdrew or did not want to socialize with their surroundings, $8 \%$ or 9 clients with violent behavior, $10 \%$ or 12 clients with delusions and suicide risk $2 \%$ or 3 clients.

Mental health directorate raise the problem of mental disorders with the greatest mental patients (70\%) were schizophrenia [8]. Schizophrenia is a severe mental disorder characterized by a decrease or an inability to communicate, impaired reality, unnatural or blunt affective, cognitive impairment and had difficulty doing daily activities [5]. Schizophrenia shows the negative symptoms of or vague like a flat affect, do not have the will, discomfort and withdraw from society. Positive symptoms or obvious symptoms which covers delusions, hallucinations, disorganized thinking, screwed up speaking and irregular behavior [9].

From that positive symptom, hallucinations is one problem that is very common in the community. Hallucinations are perceptions disorder in which the client perceives something that does not happen. One of perception of the hallucinations occur without any external stimuli that occurs. Internal stimuli are perceived as something real there by the client. Many different types of hallucinations were encountered that is auditory hallucinations, visual hallucinations, hallucinations of smell, hallucinations of taste and tactile hallucinations [10].

Hallucination is the loss of the human ability to distinguish internal stimuli (mind) and external stimuli (the outside world). Client give the perception or opinion about the object or the environment without any real stimulus. For example a client said hearing voices when no one speaks [1].

Hallucinations is the sensory perceptions of sight, touch, hearing, smell or taste without external stimuli. 70\% hallucinations are auditory hallucinations, $20 \%$ visual hallucinations, $10 \%$ hallucination of taste, tactile and olfactory.

Auditory hallucinations are one of the main symptoms of schizophrenia and are often so distressing that they contribute to suicidal behaviour. It is not uncommon for patients to be tormented by abusive commands or derisive running commentary on their behaviour. One third to nearly half of patients with hallucinations do not respond to pharmacological treatment. Although not as complex and distressing, in some form voices can be experienced by people without mental illness. In some studies $10 \%$ of men and $15 \%$ of women described hearing voices at some time. Predictive coding has also been incorporated into Friston's explanation of hallucinations. The author proposes that normal perceptual inference must include a degree of uncertainty in the same way as statistical inference is the ratio of the estimate and the standard error of this estimate. Failure to encode this uncertainty gives too much influence to the prior expectation as to what caused the sensation. This leads to a false inference (hallucination). Since the purpose of the prediction is to explain the sensation transmitted from the 'lower' level, the prior expectation cannot be generated in the absence of incoming stimuli. Hence, it is suggested, hallucination results from the excessive weight assigned to the expectation in the interaction of the prediction with the signal [11].

The impact of the patient's hallucinations are has no friends and preoccupied with their own thoughts. Hallucinations are not getting treatment and care, can further cause behavioral changes such as aggression, suicide, withdrew from the environment and could endanger themselves, others and the environment [12]

Treatment action that can be done to the client with hallucinations that is psycopharmaca treatment and electric convulsive. Nursing therapy actions that can be given is therapeutic modalities which covers individual therapy, environmental therapy, cognitive therapy, behavioral therapy, group therapy and family therapy .

\section{METHOD}

The study design used is Pre-experimental that is trial activity, which aims to find a symptom or effect, as a result of certain treatment [13]. By using the draft form (one group pre-post test design) in the intervention group that aims to knowing on the ability of the patient to control the hallucinations.

The population in this study is patients entire hallucinations in Turi Lamongan health center that total of 85 respondents. The sample that total of 80 respondents. The instrument used in this study consisted of a demographic data and questionnaire for the ability of patients to control hallucinations using SOP. Analysis of data editing, coding, scoring, tabulating. 


\section{RESULT}

Before being given an implementation strategy, the ability of a small part of clients to control normal hallucinations is 2 patients $(2,9 \%)$ and more than a partial ability to control mild hallucinations is 57 patients $(70,6 \%)$

The ability of more than a partial clients to control normal hallucinations is 52 patients $(65 \%)$ and a small part ability to control medium hallucinations is 2 patients (3\%).

TABLE I. DEMOGRAPHIC OF PATIENT

\begin{tabular}{|l|c|c|}
\hline & Number & Percent $(\%)$ \\
\hline Gender & 42 & 52.9 \\
Man & 38 & 47.1 \\
Woman & 5 & \\
\hline Age & 40 & 5.9 \\
> 20 years & 33 & 50.0 \\
21-30 years & 2 & 41.2 \\
31-45 years & & 2.9 \\
>45 years & & \\
\hline
\end{tabular}

TABLE II. THE PATIENT ABILITY TO CONTROL

\begin{tabular}{|l|c|c|}
\multicolumn{2}{c|}{ HALLUCINATIONS } \\
\hline Pre Intervention & Number & Percent (\%) \\
Normal & 2 & \\
Mild & 57 & 70.9 \\
Medium & 21 & 26.5 \\
\hline Post Intervention & & \\
Normal & 52 & 65 \\
Mild & 26 & 32 \\
Medium & 2 & 3 \\
\hline
\end{tabular}

\section{DISCUSSION}

A. The patients ability to control hallucinations before given the implementation strategy

Hallucinations implementation strategy is influenced by the ability to control hallucinations. Patients with a good ability to control hallucinations will have a good selfactualization in accepting the implementation of the strategy, otherwise if the strategy implementation with poor ability to control hallucinations will have a poor selfactualization also in receiving implementation strategy. While the ability to control it is affected by age. Most people suffering mental disorders in the productive age, while the research data shows that age of majority of patients is $21-30$ years were 40 patients $(50.0 \%)$, a small part aged $>45$ and as many as 2 patients $(2.9 \%)$.

Implementation of the action and communication strategy is a method of guidance in the implementation of an action based on the needs of patients and refers to the standard by implementing effective communication [14].

The implementation strategy of action and communication strategy is a learning method taught to nursing students in order to foster the behavior of "caring" both at the time of giving nursing care and nursing action [14].

Strategy Implementation and Communication Strategy is part of the method of clinical guidance in the manual guidance of nursing and midwife clinics as part of the formation [14].
B. The patients ability to control hallucinations after given the implementation strategy

Hallucinations is one of symptoms are often found in clients with mental disorders. Hallucinations are identical with schizophrenia. All clients with schizophrenia suffered hallucinations. Many things can be cause of hallucinations for example stressing pressure, anxiety about his condition, or often withdraw [15].

To facilitate early detection, intervention and potentially prevention of psychosis, it is essential to determine how flexibly individuals can move along the psychosis spectrum and which risk factors mediate transition to psychosis. Studies investigating transition to psychosis mainly focused on individuals at risk for psychosis who present with mild psychotic symptoms including perceptual aberrations, ideas of reference and paranoid ideation without psychotic level conviction [16].

Hallucination is one of symptoms in determining the diagnosis of clients who have psychotic, especially schizophrenic hallucinations influenced by factors [17], among others: Predisposition factor and precipitation factor. Predisposition factor such as: Genetic factors, the development factor, factors neurobiology, neurotransmitter study, biochemical factors, virus theory, psychologically, and sociocultural factors.

Deficits in cognitive and sensory processing may also underlie VH. Visual perception relies on two directions of information processing (bottom-up and top-down) that strongly interact [18]. Bottom-up processing encompasses the encoding and processing of incoming stimuli from the external world to V1 and subsequently to occipitaltemporal and occipitalparietal regions [18], [19]. Top-down processing refers to the cognitive cerebral processes of the observer (attention, knowledge and expectations) that may influence the interpretation of the information obtained through the bottom-up processes [18].

The prefrontal cortex is thought to be the source of topdown activity modulation [20]. In our study we examined the role of both directions of information processing in the occurrence of $\mathrm{VH}$ in psychosis [21].

Precipitation factor of neurobiological responses can be described: 1) Excess information process in the nervous system that receives and processes information in the thalamus and frontal brain. 2) The mechanism of electrical conductivity in the nerves is disturbed. 3) Trigger Symptoms such as health condition, environment, attitude, and behavior.

\section{The Influence Implementation Of Implementation Strategy Hallucinations To Patient Ability Controlling Hallucinations}

The implementation strategy can reduce hallucinations in patients, if the patients gets the ability control good hallucinations so the patient does not have weight hallucinations while the patients have the ability to control hallucinations enough or less will increase hallucinations. Hallucinations according to Muhith [15] are one of symptom that often found on clients with mental disorders. Hallucinations identically with schizophrenia. All clients with schizophrenia among them having hallucination. 
While the ability to control hallucinations is affected by age. Generally, people with mental disorders more common in productive age 21-30 years.

\section{CONCLUSION}

Respondents results of this study are expected to provide input, information, and increase knowledge about the relationship between the application of the implementation of the strategy against the patient's ability to control hallucinations.

\section{ACKNOWLEDGMENT}

Thanks to Health Department of Turi for giving the data for this study

\section{REFERENCES}

[1] F. Kusumawati and Y. Hartono, Buku ajar keperawatan jiwa. Jakarta: EGC, 2011

[2] H. Hardianto, "Gangguan jiwa, harus ditangani sejak awal," 2009. .

[3] D. Hawari, Pendekatan holistik pada gangguan jiwa skizofrenia. Jakarta: FKUI, 2009

[4] Sitompul, "Penderita gangguan jiwa meningkat," 2008. [Online] Available: hhtp://www.prakarsa-rakyat.org/artikel/news/artikel cetak,php?aid=30491. [Accessed: 15-Nov-2019].

[5] B. A. Keliat, Akemat, N. H. C. Daulima, and H. Nurhaeni, Keperawatan kesehatan jiwa komunitas : CMHN (Basic Course). Jakarta: EGC, 2011.

[6] Riskesdas, "Hasil Utama Riskesdas 2018," 2018.

[7] WHO, "Global mental health atlas country profile," Geneva, 2014.

[8] R. . Depkes, Riset kesehatan dasar. Jakarta: Depkes RI, 2013.

[9] S. L. Videbeck, Psychiatric mental health nursing, 5th ed. Philadelphia: Lippincott Williams \& Wilkins, 2011.
[10] A. S. Ibrahim, Skizofrenia spliting personality. Tangerang: Jelajah Nusa, 2011.

[11] J. M. Nazimek, M. D. Hunter, and P. W. R. Woodruff, "Auditory hallucinations: Expectation - perception model," Med. Hypotheses, vol. 78, pp. 802-810, 2012.

[12] W. F. Maramis, Catatan ilmu kedokteran jiwa, 2nd ed. Surabaya: Airlangga University Press, 2010.

[13] S. Notoatmodjo, Metodologi penelitian kesehatan. Jakarta: Rineka Cipta, 2010.

[14] Tim Keperawatan RSUP Sanglah, Buku pedoman bimbingan praktik klinik perawat / bidan RSUP Sanglah. Bali: RSUP Sanglah, 2010.

[15] A. Muhith, Pendidikan keperawatan jiwa (teori dan aplikasi). Yogyakarta: Andi, 2015.

[16] P. Fusar-Poli et al., "The psycchosis high-risk state: a comperehensive state-of-the-art review," JAMA Psychiatry, vol. 70, pp. 107-120, 2013.

[17] G. W. Stuart, Principles and practice of psychiatric nursing, 10th ed. St Louis, Missouri: Mosby Elsevier Inc, 2015.

[18] A. Aleman and F. Laroi, Cognitive-perceptual processes: bottom-up and top-down. InHallucinations: The Science of Idiosyncratic Perception, 1st ed. Washington DC: American Psychological Association, 2008.

[19] A. Mac Meppelink, J. Koerts, M. Borg, K. L. Leenders, and Teo Van-Laar, "Visual object recognition and attention in Parkinson's disease patients with visual hallucinations," Mov. Disord., vol. 23, pp. 1906-1912, 2008.

[20] T. P. Zanto, M. T. Rubens, A. Thangavel, and A. Gazzaley, "Causal role of the prefrontal cortex in top-down modulation of visual processing and working memory," Nat. Neurosci., vol. 14, pp. 656-661, 2011.

[21] M. M. Van Ommen, M. Van Beilen, F. W. Cornelissen, H. G. O. M. Smid, and H. Knegtering, "The prevalence of visual hallucinations in non-affective psychosis, and the role of perception and attention," Psychol. Med., vol. 46, pp. 17351747, 2016. 